\title{
ЗАЩИТА РАСТЕНИЙ
}

\section{ОПРЕДЕЛЕНИЕ ГЕНОВ УСТОЙЧИВОСТИ К БУРОЙ РЖАВЧИНЕ У СОРТОВ ОЗИМОЙ МЯГКОЙ ПШЕНИЦЫ С ИСПОЛЬЗОВАНИЕМ ТРАДИЦИОННЫХ И СОВРЕМЕННЫХ МЕТОДОВ ИССЛЕДОВАНИЙ}

Н. В. Шишкин ${ }^{1}$, кандидат сельскохозяйственных наук, ведущий научный сотрудник лаборатории иммунитета и защиты растений, nik.shiskin.1961@mail.ru, ORCID ID: 0000-0003-3863-0297;

Т. Г. Дерова ${ }^{1}$, ведущий научный сотрудник лаборатории иммунитета и защиты растений, derova06@rambler.ru, ORCID ID: 0000-0001-7969-054X;

Е. И. Гультяева², кандидат биологических наук, ведущий научный сотрудник лаборатории микологии и фитопатологии, ORCID ID: 0000-0001-7948-0307;

Е. Л. Шайдаюк², младший научный сотрудник лаборатории микологии и фитопатологии, ORCID ID: 0000-0003-3266-6272

${ }_{1}^{1}$ ФГБНУ «Аграрный научный центр «Донской»

347740, Ростовская обл., г. Зерноград, Научный городок, 3;

${ }^{2}$ ФГБНУ Всероссийский научно-исследовательский институт защиты растений

196608, г. Санкт-Петербург, г. Пушкин, шоссе Подбельского, 3

Бурая ржавчина - основное заболевание сортов мягкой пшеницы на посевах в Ростовской области. Сорта пшеницы, созданные в ФГБНУ «АНЦ «Донской», в большинстве (более $87 \%$ ) проявляют устойчивость к данному возбудителю. С целью получения полной иммунологической характеристики созданных сортов совместно с лабораторией микологии и фитопатологии ФГБНУ ВИЗР были проведены исследования по идентификации генов устойчивости (Lr) на ранних этапах развития и во взрослом состоянии растений. Изучено 37 сортов озимой мягкой пшеницы на полевых инфекционных фонах юга и северо-запада России, в том числе методами фитопатологического теста (к трем изолятам гриба с вирулентностью к TCLR9, TCLR19, TCLR26 и зерноградской популяции патогена) и методом ПЦР-анализа с помощью 10 молекулярных маркеров: LR1, LR3, LR9, LR10, LR19, LR20, LR24, LR26, LR34 и LR37. ДНК выделяли микрометодом по К. Эдвардс, ПЦР проводили в амплификаторе C-1000 (BIO RaD, США). В результате исследований установлено, что универсально устойчивых ко всем трем клонам и зерноградской популяции среди изученных сортов не выявлено. Сорта Полина, Вольница и Зерноградка 11 проявили устойчивость к трем клонам, но в фразу проростка проявляли восприимчивость к популяции патогена. По результатам ПЦР-анализа также не выявлено у сортов генов устойчивости Lr9, Lr19, Lr24, Lr26. У 29 из 37 изученных сортов обнаружен ген взрослой устойчивости Lr34, а у 20 сортов - неэффективный ген Lr3, которые по отдельности и вместе не могут обеспечивать защиту от бурой ржавчины в полевых условиях. Это указывает на то, что устойчивые в полевых условиях сорта несут дополнительные неидентифицированные Lr-гены. У ряда сортов установлено по 2 гена устойчивости. Восприимчивый в полевых условиях сорт Кипчак содержит утративший свою эффеективность ген Lr1. Различия в степени поражения отдельных сортов в условиях Ростовской области и Санкт-Петербурга свидетельствуют об отличии северокавказской и северо-западной популяций по вирулентности к возбудителю бурой ржавчины.

Ключевые слова: озимая пшеница, бурая ржавчина, гены Lr, устойчивость, ПЦР-анализ.

(cc) $\mathrm{BY}$

\section{IDENTIFICATION OF THE GENES RESISTANT TO BROWN RUST IN WINTER SOFT WHEAT VARIETIES WITH THE USE OF CONVENTIONAL AND MODERN RESEARCH METHODS}

N. V. Shishkin', Candidate of Agricultural Sciences, leading researcher of the laboratory of plant immunity and protection, nik.shiskin.1961@mail.ru, ORCID ID: 0000-0003-3863-0297;

T. G. Derova ${ }^{1}$, leading researcher of the laboratory for plant immunity and protection, derova06@rambler.ru, ORCID ID: 0000-0001-7969-054X;

E. I. Gultyaeva2 ${ }^{2}$ Candidate of Biological Sciences, leading researcher of the laboratory of microbiology and phytopathology, ORCID ID: 0000-0001-7948-0307;

E. L. Shaydayuk ${ }^{2}$, junior researcher of the laboratory of microbiology and phytopathology, ORCID ID: 0000-00033266-6272

${ }^{1}$ FSBSI "Agricultural Research Center "Donskoy"

347740, Rostov region, Zernograd, Nauchny Gorodok, 3;

${ }^{2}$ FSBSI All-Russian Research Institute of Plant Protection

196608, Saint-Petersburg, Pushkin, Av. Podbelsky, 3

Brown rust is the main disease of wheat soft varieties in the Rostov region. The majority of wheat varieties (more than $87 \%$ ) developed in the FSBSI "Agricultural Research Center "Donskoy" show resistance to this causative agent. In order to obtain a complete immunological characteristics of the developed varieties, there were carried out the researches to identify the resistance genes (Lr) in the early and adult stages of plant growing in cooperation with the Mycology and Phytopathology Laboratory of the FSBSI ARIZR. There were studied 37 varieties of winter soft wheat on the infectious fields of the south and northwest of Russia, as well as by the methods of a phytopathological test (to three isolates of the fungus with virulence to TcLr9, TcLr19, TcLr26 and the Zernograd pathogen population) and by the PCR analysis using 10 molecular markers Lr1, Lr3, Lr9, Lr10, Lr19, Lr20, Lr24, Lr26, Lr34 and Lr37. DNA was isolated by a micro-method according to K. Edwards, the PCR was carried out in a C-1000 amplifier (Bio Rad, US). The study established that there were no universal varieties among the studied ones which were resistant to all 
three clones and the Zergograd population. The varieties "Polina", "Volnitsa" and "Zernogradka 11" showed resistance to the three clones, but in the phase of sprouting they show susceptibility to the pathogen population. According to the results of PCR analysis, the resistance genes Lr9, Lr19, Lr24, Lr26 were also not found in the varieties. 29 out of 37 studied varieties contained the adult resistance gene Lr34, and 20 varieties had the inefficient gene Lr3, which neither apart nor together could protect the plants from brown rust in the field. This indicates that the tolerant varieties carry additional non-identified Lr-genes. In a number of varieties there have been established 2 resistance genes. The variety "Kipchak" susceptible in the field contained the Lr1 gene, which lost its effectiveness. The differences in the damage degree of some varieties in the conditions of the Rostov region and St. Petersburg indicate a difference in the North Caucasian and northwestern populations by virulence to the causative agent of brown rust.

Keywords: winter wheat, brown rust, genes Lr, tolerance (resistance), PCR-analysis.

Введение. В хозяйствах Ростовской области высевают большое количество сортов озимой мягкой пшеницы с разной степенью устойчивости к фритопатогенным организмам. Показатели величины и качества урожая культуры находятся под непосредственной угрозой не только из-за погодных условий, негативно сказывающихся на развитии растений, но и патогенных грибов, среди которых немаловажную роль играет бурая ржавчина (Puccinia triticina Erikss.).

Несмотря на всестороннее изучение этого заболевания, защита озимой пшеницы от бурой ржавчины по-прежнему остается актуальной проблемой. Распространение и развитие заболевания происходят в результате заноса, накопления и сохранения активной инфекции (Данилова и Волкова, 2015). Кроме того, одной из главных причин усиления вредоносности является непрерывный эволюционный процесс, в результате которого образуются новые вирулентные расы и патотипы гриба.

Более $87 \%$ сортов озимой мягкой пшеницы, созданных в ФГБНУ «АНЦ «Донской», обладают различной степенью устойчивости к бурой ржавчине. В рамках совместных исследований была проведена идентификация генов устойчивости созданных сортов к бурой ржавчине в лаборатории микологии и фритопатологии ФГБНУ ВИЗР (г. Санкт-Петербург), а также изучена ювенильная устойчивость сортов пшеницы к клонам различных популяций, тестирующих эффрективные гены устойчивости данного возбудителя.

Материалы и методы исследований. Объектом исследований были 37 сортов озимой пшеницы, созданные в ФГБНУ «АНЦ «Донской». Все сорта изучали на полевом инфекционном фоне в ФГБНУ «АНЦ «Донской» (г. Зерноград), а часть сортов - на инфекционном фоне в ВИЗР (г. Санкт-Петербург). Опыты проводили на основе общепринятых методик и оценок. Заражение сортов пшеницы проводили при температуре $10-12{ }^{\circ} \mathrm{C}$ в фразу кущения - трубкования путем опудривания смесью жизнеспособных урединиоспор. Оценку сортов озимой пшеницы по интенсивности поражения бурой ржавчины проводили по шкале R. F. Peterson (1948).

Для изучения ювенильной устойчивости сортов пшеницы в фразе проростков проводили инокуляцию проростков клонами из Челябинской, Тамбовской областей, Краснодарского края и зерноградской популяцией возбудителя бурой ржавчины (табл. 1).

\section{1. Характеристика инфекционного материала по вирулентности к TcLr-линиям} 1. Characteristic of infectious material by virulence to TcLr lines

\begin{tabular}{|l|l|l|l|}
\hline Изолят & \multicolumn{1}{|c|}{ Происхождение } & \multicolumn{1}{|c|}{ Вирулентность к TcLr } & Авирулентность к TcLr \\
\hline К1 & Челябинский клон, 2016 & 1, 2a, 2b, 2c, 3a, 3bg, 3ka, 9, 10, 11, 14a, 14b, 15, 16, 17, 18, 20, 30 & 19, 24, 26, 28, 29 \\
\hline К2 & Тамбовский клон, 2016 & 1, 2a, 2b, 2c, 3a, 3bg, 3ka, 10, 11, 14a, 14b, 15, 16, 17, 18, 19, 20, 30 & 9, 24, 26, 28, 29 \\
\hline К3 & $\begin{array}{l}\text { Краснодарский клон, } \\
\text { 2016 }\end{array}$ & $\begin{array}{l}\text { 1, 2a, 2b, 2c, 3a, 3bg, 3ka, 10, 11, 14a, 14b, 15, 16, 17, 18, 20, 21, } \\
\text { 26, 30 }\end{array}$ & $9,19,24,28,29$ \\
\hline П_3ер & $\begin{array}{l}\text { Зерноградская } \\
\text { популяция, 2017 }\end{array}$ & 1, 2c, 3a, 3bg, 3ka, 10, 11, 14a, 14b, 16, 17, 18, 19, 20, 30 & $\begin{array}{l}\text { 9, 2a, 2b, 15, 19, 24, } \\
28,29\end{array}$ \\
\hline
\end{tabular}

Анализ вирулентности проводили на 10-14-дневных проростках пшеницы (фаза первого листа), которые инокулировали суспензией возбудителя, помещали во влажную камеру на 12-18 часов и далее инкубировали при температуре $20-24{ }^{\circ} \mathrm{C}$ (Гультяева и Солодухина, 2006). Учет проводили на 10-й день после заражения по балловой шкале Е. B. Mains и H. S. Jackson (1926), где: 0, 1, 2 балла - устойчивый тип; 3, 4 и X- восприимчивый.

Была проведена идентификация генов Lr1, Lr3, Lr9, Lr10, Lr19, Lr20, Lr24, Lr26, Lr34 и Lr37 с использованием молекулярных маркеров сортов озимой мягкой пшеницы. Список используемых маркеров представлен в таблице 2. ДНК выделяли микрометодом, предложенным К. Эдвардс с соавторами в модификации Д. Б. Дорохова и Э. Клоке (1997). Концентрация ДНК в рабочем растворе составляла 50-100 нг/мкл. Полимеразную цепную реакцию (ПЦР) проводили в амплификаторе C-1000 (BioRad, США) по протоколам, предложенным авторами праймеров (табл. 2), и при необходимости модифицировали. Амплифицированные фрагменты разделяли с помощью электрофореза в 1,5\% агарозном геле в 1хTВE буфере, который был окрашен бромистым этидием.

Результаты и их обсуждение. Часть сортов, включенных в Государственный реестр селекционных достижений, были оценены по устойчивости к возбудите- лю бурой ржавчины в условиях северо-запада России В период 2010-2015 гг. их высевали на опытном поле ВИР и искусственно инокулировали сборной северо-западной популяцией. Из 15 сортов 47\% были устойчивые, 7\% - слабовосприимчивые и 46\% - восприимчивые (табл. 3).

Большая часть из 37 изучаемых сортов (73\%) в полевых условиях при искусственном заражении северокавказской популяцией на опытном поле ФГБНУ «АНЦ «Донской» бурой ржавчины проявили высокую устойчивость (поражение не выше 15\%), 10,8\% сортов были слабовосприимчивыми (поражение до 20-30 \%) и $16,2 \%$ сортов имели поражение выше $50 \%$.

При инокуляции изученных сортов мягкой пшеницы универсально устойчивых ко всем клонам и зерноградской популяции не выявлено. Устойчивостью к трем клонам характеризовались сорта Полина, Вольница и Зерноградка 11, но все сорта в фазе проростка проявили восприимчивость к популяции патогена (табл. 3).

Ген Lr34 относится к группе генов, контролирующих частичную устойчивость в фразе взрослых растений, но, по данным J. A. Kolmer (2002), сочетание гена Lr34 с одним или двумя другими расоспецифическими генами может значительно повысить уровень полевой устойчивости, что и наблюдается в наших исследованиях. 


\section{2. Список использованных маркеров}

2. List of used markers

\begin{tabular}{|c|c|c|c|c|}
\hline Ген & $\begin{array}{c}\text { Название } \\
\text { маркера }\end{array}$ & Нуклеотидная последовательность & $\begin{array}{c}\text { Размер } \\
\text { п. о. }\end{array}$ & Литературный источник \\
\hline \multirow{2}{*}{ Lr1 } & WR003F & GGGACAGAGACCTTGGTGGA & \multirow{2}{*}{760} & \multirow{2}{*}{ Qiu et al., 2007} \\
\hline & WR003R & GACGATGATGATTTGCTGCTGG & & \\
\hline \multirow{2}{*}{ Lr3 } & Xmwg798F & GGCTGTCTACATCTTCTGCA & \multirow{2}{*}{365} & \multirow{2}{*}{ Herrera-Foessel et al., 2007} \\
\hline & Xmwg798R & CAAGTGTTGAGAAGGAGAGT & & \\
\hline \multirow{2}{*}{ Lr9 } & SCS5F & TGCGCCCTTCAAAGGAAG & \multirow{2}{*}{550} & \multirow{2}{*}{ Gupta et al., 2005} \\
\hline & SCS5R & TGCGCCCTTCTGAACTGTAT & & \\
\hline \multirow{2}{*}{ Lr10 } & Fi.2245 & GTGTAATGCATGCAGGTTCC & \multirow{2}{*}{310} & \multirow{2}{*}{ Chelkowski et al., 2008} \\
\hline & Lr10-6/r2 & AGGTGTGAGTGAGTTATGTT & & \\
\hline \multirow{2}{*}{ Lr19 } & SCS265 F & GGCGGATAAGCAGAGCAGAG & \multirow{2}{*}{512} & \multirow{2}{*}{ Gupta et al., 2006} \\
\hline & SCS265 R & GGCGGATAAGTGGGTTATGG & & \\
\hline \multirow{2}{*}{ Lr20 } & STS638-L & ACAGCGATGAAGCAATGAAA & \multirow{2}{*}{542} & \multirow{2}{*}{ Neu et al., 2002} \\
\hline & STS638-R & GTCCAGTTGGTTGATGGAAT & & \\
\hline \multirow{2}{*}{ Lr24 } & $\mathrm{Sr} 24 \neq 12 \mathrm{~F}$ & CACCCGTGACATGCTCGTA & \multirow{2}{*}{550} & \multirow{2}{*}{ Mago et al., 2005} \\
\hline & Sr24\#12R & AACAGGAAATGAGCAACGATGT & & \\
\hline \multirow{2}{*}{ Lr26 } & SCM9F & TGACAACCC CCTTTCCCTCGT & \multirow{2}{*}{207} & \multirow{2}{*}{ Weng et al., 2007} \\
\hline & SCM9R & TCATCGACGCTAAGGAGGACCC & & \\
\hline \multirow{2}{*}{ Lr34 } & csLV34F & GTTGGTTAAGACTGGTGATGG & \multirow{2}{*}{150} & \multirow{2}{*}{ Lagudah et al., 2006} \\
\hline & csLV34F & TGCTTGCTATTGCTGAATAGT & & \\
\hline \multirow{2}{*}{ Lr37 } & Venttriup & AGGGGCTACTGACCAAGGCT & \multirow{2}{*}{259} & \multirow{2}{*}{ Helguera et al., 2003} \\
\hline & LN2 & TGCAGCTACAGCAGTATGTACACAAAA & & \\
\hline
\end{tabular}

\section{3. Иммунологическая характеристика сортов озимой мягкой пшеницы селекции ФГБНУ «Аграрный научный центр «Донской»}

3. Immunological characteristics of winter soft wheat varieties developed by the FSBSI "Agricultural Research Center "Donskoy"

\begin{tabular}{|c|c|c|c|c|c|c|c|}
\hline \multirow[t]{2}{*}{ Сорт } & \multicolumn{4}{|c|}{ Инокулянт и тип поражения } & \multirow{2}{*}{$\begin{array}{c}\text { Lr-гены, идентифици- } \\
\text { рованные с помощью MM* }\end{array}$} & \multicolumn{2}{|c|}{$\begin{array}{c}\text { Степень поражения на } \\
\text { инфекционных фронах, \% }\end{array}$} \\
\hline & К1 & K2 & K3 & 3. n.* $^{* *}$ & & г. Зерноград & г. Санкт-Петербург \\
\hline Аксинья & 3 & 0 & 3 & 3 & Lr34 Lr3 & $5-10$ & 0 \\
\hline Бонус & 3 & 3 & 0 & 3 & Lr34 Lr1 Lr3 & $0-5$ & $=$ \\
\hline Донская безостая & 3 & 3 & 3 & 3 & Lr34 Lr3 & $10-15$ & $50-70$ \\
\hline Донская юбилейная & 3 & 3 & 3 & 3 & Lr34 Lr3 & $20-30$ & $=$ \\
\hline Зерноградка 10 & 3 & 3 & 3 & 3 & Lr34 Lr3 & $5-10$ & $=$ \\
\hline Зерноградка 11 & $1-2$ & $1-2$ & 0 & - & Lr34 & $0-5$ & $50-70$ \\
\hline Казачка & 3 & - & 0 & 3 & Lr34 Lr3 & $5-10$ & $=$ \\
\hline Кипчак & - & 3 & 3 & 3 & Lr1 & $60-80$ & $=$ \\
\hline Конкурент & 3 & - & 0 & 3 & Lr34 & $0-5$ & $=$ \\
\hline Лучезар & 3 & 0 & 0 & 3 & Lr3 & 0 & $=$ \\
\hline Мараффон & 3 & 3 & 3 & 3 & Lr34 & $0-5$ & 30 \\
\hline Находка & 3 & 3 & 3 & 3 & Lr34 & $0-5$ & 0 \\
\hline Ростовчанка 3 & 3 & 3 & 0 & - & Lr34 & $50-60$ & 50 \\
\hline Ростовчан-ка 5 & 3 & 3 & 3 & 3 & Lr3 & $5-10$ & 10 \\
\hline Ростовчанка 7 & 3 & 3 & 3 & - & Lr3 & $5-10$ & $10-20$ \\
\hline Танаис & 3 & 0 & 3 & 3 & Lr34 & $5-10$ & $=$ \\
\hline Шеф & 3 & 3 & 3 & 3 & Lr34 Lr10 & $15-20$ & $=$ \\
\hline Этюд & 3 & 0 & 0 & 3 & Lr3 & 0 & $=$ \\
\hline Адмирал & 3 & 0 & 3 & 3 & Lr34 Lr3 & 0 & $=$ \\
\hline Аскет & 3 & $2-3$ & 3 & 3 & Lr34 Lr3 & $0-5$ & 10 \\
\hline Вольница & $0-2$ & 0 & 0 & 3 & Lr34 Lr1 & $20-30$ & $=$ \\
\hline Вольный Дон & 3 & 3 & 3 & 3 & Lr34 & $15-20$ & $=$ \\
\hline Дон 93 & 3 & 2 & 3 & 3 & Lr34 Lr3 & $5-10$ & $=$ \\
\hline Дон107 & 3 & 0 & 3 & 3 & Lr34 Lr1 & $60-80$ & 70 \\
\hline Донской сюрприз & 3 & 3 & 3 & 3 & Lr34 Lr3 & $0-5$ & $=$ \\
\hline Донской маяк & 3 & 3 & 3 & 3 & Lr34 Lr3 & $10-15$ & 50 \\
\hline Донской простор & 3 & 3 & 0 & 3 & Lr34 Lr3 & $50-60$ & 50 \\
\hline Ермак & 3 & 3 & 3 & 3 & Lr3 & $10-15$ & $=$ \\
\hline Жаворонок & 3 & 3 & 3 & 3 & Lr34 & 0 & $=$ \\
\hline Изюминка & 3 & 3 & 3 & 3 & Lr34 Lr3 & $5-10$ & $5-10$ \\
\hline Капитан & 3 & 3 & 3 & 3 & Lr34 Lr3 & $5-10$ & $=$ \\
\hline Капризуля & 3 & 0 & 3 & 3 & Lr34 & $50-60$ & $=$ \\
\hline Краса Дона & 3 & 3 & 3 & 3 & Lr3 Lr1 & $0-5$ & $=$ \\
\hline Лидия & 3 & 3 & 3 & 3 & Lr34 Lr3 & $5-10$ & 0 \\
\hline Лилит & 3 & - & 3 & 3 & Lr34 Lr3 & $50-60$ & $=$ \\
\hline Полина & $1-2$ & $0-1$ & $0-1$ & 3 & - & $0-5$ & $=$ \\
\hline Станичная & 3 & 3 & 3 & 3 & Lr34 & $0-5$ & 50 \\
\hline
\end{tabular}

* ММ - молекулярные маркеры; ** 3. п. - зерноградская популяция; = - не изучались на инфекционном фроне ВИЗР. 
Много лет устойчивость проявляют сорта, содержащие гены устойчивости Lr34 и Lr3 как вместе (Аксинья, Бонус, Зерноградка 10, Казачка, Адмирал, Аскет, Дон 93, Донской сюрприз, Донской маяк, Изюминка, Капитан, Лидия), так и по отдельности: Lr34 - Зерноградка 11, Конкурент, Марафон, Находка, Танаис, Жаворонок, Станичная; Lr3 - Лучезар, Ростовчанка 5, Ростовчанка 7, Этюд. Гены Lr34 и Lr3 являются неэффективными в России. Вероятно, данные сорта наряду с этими генами несут дополнительные гены, которые не определены в данных исследованиях изза отсутствия молекулярных маркеров.

Для сортов Находка, Бонус, Конкурент, Аксинья, Казачка, Донская безостая, Изюминка, Зерноградка 9, Зерноградка 10 и Зерноградка 11 сведения о наличии гена Lr34 согласуются с исследованиями Н. Н. Вожжовой (2018).

Различия в поражении отдельных сортов клонами и популяциями из разных регионов (Донская безостая, Зерноградка 11, Марафон, Донской маяк, Станичная) могут указывать на наличие у них дополнительных ювенильных Lr-генов (табл. 3).

Выводы. С использованием клонов, маркированных вирулентностью к генам Lr9, Lr19 и Lr26, данных генов у изученных сортов не выявлено, что подтверждается и результатами, полученными с использованием молекулярных маркеров. С использованием маркера у изучаемых образцов также не выявлен ген Lr24. При этом, согласно ПЦР-анализу, у них широко представлены ген взрослой устойчивости Lr34 и малоэффективный ген Lr3 (табл. 3). У сорта Шеф наряду с геном Lr34 выявлен малоэффрективный ген Lr10, а у сортов Бонус, Дон 107, Вольница - ген Lr1. У сорта Кипчак идентифицирован только неэффективный ген Lr1, что подтверждается его восприимчивостью на инфекционном фоне возбудителя.

Различия в степени поражения отдельных сортов (Донская безостая, Зерноградка 11, Донской маяк и др.) в условиях Ростовской области и Санкт-Петербурга свидетельствуют об отличии северокавказской и северо-западной популяций возбудителя бурой ржавчины.

Для успешной селекции на устойчивость к вредным организмам целесообразно и эффеективно сочетать полевые исследования с лабораторными с использованием молекулярных маркеров. Молекулярные маркеры более актуальны в фундаментальных исследованиях.

\section{Библиографические ссылки}

1. Вожжова Н. Н. Идентификация гена устойчивости к бурой ржавчине Lr34 в сортах и коллекционных образцах озимой мягкой пшеницы Аграрного научного центра «Донской» // Вавиловский журнал генетики и селекции. 2018. № 22(3). С. 329-332. DOI 10.18699/VJ18.368.

2. Гультяева Е. И., Солодухина О. В. Ржавчинные болезни зерновых культур. Изучение генетических ресурсов зерновых культур по устойчивости к вредным организмам. М.: Книга, 2008. С. 5-11.

3. Данилова А. В., Волкова Г. В. Карликовая ржавчина - прогрессирующее заболевание ячменя // Защита и карантин растений. 2015. № 7. С. 46-48.

4. Дорохов Д. Б., Клоке Э. Быстрая и экономичная технология RAPD анализа растительных геномов // Молекулярная генетика. 1997. Т. 3, № 4. С. 443-450.

5. Chelkowski J., Golka L., Steptien I. Application of STS marker for leaf rust resistance genes in near-isogenic lines of spring wheat cv. Tratcher // J. Appl. Genet. 2003. Vol. 44. Pp. 323-338.

6. Gupta S. K., Charpe A., Koul S., Prabhu K. V., Haq Q. M. Development and validation of molecular markers linked to an Aegilops umbellulata-derived leaf rust-resistance gene, Lr9, for marker-assisted selection in bread wheat // Genome. 2005. Vol. 48, No. 5. Pp. 823-830.

7. Gupta S. K., Charpe A., Prabhu K. W., Haque O. M. R. Identification and validation of molecular markers linked to the leaf rust resistance gene Lr19 in wheat // Theor. Appl. Genet. 2006. Vol. 113. Pp. 1027-1036.

8. Helguera M., Khan I. A., Kolmer J., Lijavetzky D., Zhong-qi L., Dubcovsky J. PCR assays for the Lr37-Yr17-Sr38 cluster of rust resistance genes and their use to develop isogenic hard red spring wheat lines // Crop Science. 2003. Vol. 43. Pp. 1839-1847.

9. Herrera-Foessel S. A., Singh R. P., Huerta-Espino J., William M., Rosewarne G., Djurle A., Yuen J. Identifi cation and Mapping of Lr3 and a Linked Leaf Rust Resistance Gene in Durum Wheat // CROP SCIENCE. 2007. Vol. 47. Pp. 1459-1466.

10. Kolmer J. A. Virulence phenotypes of puccinia triticina in South Atiantik in 1999 // Plant Diseases. 2002. No. 88(3). Pp. 288-291.

11. Lagudah E. S., McFadden H., Singh R. P., Huerta-Espino J., Bariana H. S., Spielmeyer W. Molecular genetic characterization of the Lr34/Yr18 slow rusting resistance gene region in wheat // Theor. Appl. Genet. 2006. Vol. 114. Pp. 21-30.

12. Mago R., Bariana H. S., Dundas I. S., Spielmeyer W., Lawrence G. J., Pryor A. J., Ellis J. G. Development or PCR markers for the selection of wheat stem rust resistance genes Sr24 and Sr26 in diverse wheat germplasm // Theor. Appl. Genet. 2005. Vol. 111. Pp. 496-504.

13. Mains E. B., Jackson H. S. Physiological specialization in leaf rust of wheat? Puccinia triticina Erikss. // Phytopathology. 1926. Vol. 16. Pp. 89-120.

14. Neu C. H. et al. Genetic mapping of the Lr 20-Pml resistance locus reveals suppressed recombination on chromosome arm 7AL in hexaploid wheat // Genome. 2002. Vol. 45. Pp. 737-744.

15. Peterson R. F. A diagrammatic scale for estimating rust intensity jn leaves and stem of cereals // Can. J. Res. 1948. Vol. 26. Pp. 496-500.

16. Qiu J. W., Schürch A. C., Yahiaoui N., Dong L. L., Fan H. J., Zhang Z. J., Keller B., Ling H. Q. Physical mapping and identification of a candidate for the leaf rust resistance gene Lr1 of wheat // Theor Appl Genet. 2007. Vol. 115. Pp. 159-168.

17. Weng Y., Azhaguvel P., Devkota R. N., Rudd J. C. PCR based markers for detection of different sources of 1AL.1RS and 1BL.1RS wheat-rye translocations in wheat background. Plant Breed. 2007. Vol. 126. Pp. $482-486$.

\section{References}

1. Vozhzhova N. N. Identifikaciya gena ustojchivosti k buroj rzhavchine Lr34 v sortah i kollekcionnyh obrazcah ozimoj myagkoj pshenicy Agrarnogo nauchnogo centra "Donskoj" [Identification of the gene resistant to brown rust 
Lr34 in the varieties and collection samples of winter soft wheat developed by the FSBSI "Agricultural Research Center "Donskoy"] // Vavilovskij zhurnal genetiki i selekcii. 2018. № 22(3). S. 329-332. DOI 10.18699/VJ18.368.

2. Gul'tyaeva E. I., Soloduhina O. V. Rzhavchinnye bolezni zernovyh kul'tur. Izuchenie geneticheskih resursov zernovyh kul'tur po ustojchivosti k vrednym organizmam [Rust diseases of grain crops. The study of genetic resources of grain crops for their resistance to pests]. M.: Kniga, 2008. S. 5-11.

3. Danilova A. V., Volkova G. V. Karlikovaya rzhavchina - progressiruyushchee zabolevanie yachmenya [Dwarf rust is a progressive barley disease] // Zashchita i karantin rastenij. 2015. № 7. S. 46-48.

4. Dorohov D. B., Kloke Eh. Bystraya i ehkonomichnaya tekhnologiya RAPD analiza rastitel'nyh genomov [Rapid and economical technology of RAPD analysis of plant genomes] // Molekulyarnaya genetika. 1997. T. 3 , № 4 . S. $443-450$

5. Chelkowski J., Golka L., Steptien I. Application of STS marker for leaf rust resistance genes in near-isogenic lines of spring wheat cv. Tratcher. // J. Appl. Genet. 2003. Vol. 44. Pp. 323-338.

6. Gupta S. K., Charpe A., Koul S., Prabhu K. V., Haq Q. M. Development and validation of molecular markers linked to an Aegilops umbellulata-derived leaf rust-resistance gene, Lr9, for marker-assisted selection in bread wheat // Genome. 2005. Vol. 48, No. 5. Pp. 823-830.

7. Gupta S. K., Charpe A., Prabhu K. W., Haque O. M. R. Identification and validation of molecular markers linked to the leaf rust resistance gene Lr19 in wheat // Theor. Appl. Genet. 2006. Vol. 113. Pp. 1027-1036.

8. Helguera M., Khan I. A., Kolmer J., Lijavetzky D., Zhong-qi L., Dubcovsky J. PCR assays for the Lr37-Yr17-Sr38 cluster of rust resistance genes and their use to develop isogenic hard red spring wheat lines // Crop Science. 2003. Vol. 43. Pp. 1839-1847.

9. Herrera-Foessel S. A., Singh R. P., Huerta-Espino J., William M., Rosewarne G., Djurle A., Yuen J. Identifi cation and Mapping of Lr3 and a Linked Leaf Rust Resistance Gene in Durum Wheat // CROP SCIENCE. 2007. Vol. 47. Pp. 1459-1466.

10. Kolmer J. A. Virulence phenotypes of puccinia triticina in South Atiantik in 1999 // Plant Diseases. 2002. No. 88(3). Pp. 288-291.

11. Lagudah E. S., McFadden H., Singh R. P., Huerta-Espino J., Bariana H. S., Spielmeyer W. Molecular genetic characterization of the Lr34/Yr18 slow rusting resistance gene region in wheat // Theor. Appl. Genet. 2006. Vol. 114 Pp. 21-30.

12. Mago R., Bariana H. S., Dundas I. S., Spielmeyer W., Lawrence G. J., Pryor A. J., Ellis J. G. Development or PCR markers for the selection of wheat stem rust resistance genes Sr24 and Sr26 in diverse wheat germplasm // Theor. Appl. Genet. 2005. Vol. 111. Pp. 496-504.

13. Mains E. B., Jackson H. S. Physiological specialization in leaf rust of wheat? Puccinia triticina Erikss. // Phytopathology. 1926. Vol. 16. Pp. 89-120.

14. Neu C. H. et al. Genetic mapping of the $\mathrm{Lr} 20-\mathrm{Pml}$ resistance locus reveals suppressed recombination on chromosome arm 7AL in hexaploid wheat // Genome. 2002. Vol. 45. Pp. 737-744.

15. Peterson R. F. A diagrammatic scale for estimating rust intensity jn leaves and stem of cereals // Can. J. Res. 1948. Vol. 26. Pp. 496-500.

16. Qiu J. W., Schürch A. C., Yahiaoui N., Dong L. L., Fan H. J., Zhang Z. J., Keller B., Ling H. Q. Physical mapping and identification of a candidate for the leaf rust resistance gene Lr1 of wheat // Theor Appl Genet. 2007. Vol. 115. Pp. 159-168.

17. Weng Y., Azhaguvel P., Devkota R. N., Rudd J. C. PCR based markers for detection of different sources of 1AL.1RS and 1BL.1RS wheat-rye translocations in wheat background. Plant Breed. 2007. Vol. 126. Pp. $482-486$.

Критерии авторства. Авторы статьи подтверждают, что несут ответственность за плагиат.

Конфрликт интересов. Авторы заявляют об отсутствии конфрликта интересов.

\section{РОЛЬ ИСХОДНОГО МАТЕРИАЛА В СЕЛЕКЦИИ РЖАВЧИНОУСТОЙЧИВЫХ СОРТОВ МЯГКОЙ ЯРОВОЙ ПШЕНИЦЫ В УСЛОВИЯХ ЗАУРАЛЬЯ}

Л. Т. Мальцева, кандидат сельскохозяйственных наук, ведущий научный сотрудник, ORCID ID: 0000-00032926-0933;

E. А. Филиппова, старший научный сотрудник, ORCID ID: 0000-0001-8209-9603;

H. Ю. Банникова, старший научный сотрудник, ORCID ID: 0000-0002-0395-5924;

B. А. Бердюгин, научный сотрудник, ORCID ID: 0000-0002-2703-7781

ФГБНУ «Уральский федеральный аграрный научно-исследовательский центр Уральского отделения Российской академии наук» г. Екатеринбург

620142, г. Екатеринбург, ул. Белинского, 112a; e-mail: kniish@ketovo.zaural.ru

Одним из фракторов, ограничивающих рост урожайности пшеницы в Зауралье, является поражение посевов листостебельными болезнями, проявляющимися с регулярностью три раза в десять лет, унося от 5 до 30\% урожая. В $2015-2017$ гг. на фоне эпифитотий бурой и стеблевой ржавчины из 17 районированных сортов яровой мягкой пшеницы высокую толерантность проявили лишь два сорта - Радуга (Курганский НИИСХ) и Уралосибирская (СибНИИСХоз), занимающие в области всего 8-9\% площади. Для создания новых сортов привлечены генетические коллекции отечественного и зарубежного происхождения. На эпифитотийном фоне выявлены сорта и образцы с эффрективными генами устойчивости. Целенаправленно проведен отбор в гибридных популяциях. Оценены морфологически выровненные линии для размножения. Для ускоренного создания новых сортов предложен устойчивый и толерантный к болезням, адаптивный к местным условиям исходный материал из коллекционного питомника: сорта Сигма, Памяти Леонтьева, Боевчанка, Фаворит, Новосибирская 31, Ингала, Сударыня, Геракл, 